\title{
Immunological changes in growing mice fed on diets containing casein or peas (Pisum sativum var. Belinda) as the source of protein
}

\author{
BY J. ALFREDO MARTÍNEZ, M. LUISA ESPARZA AND JESÚS LARRALDE \\ Department of Physiology and Nutrition, University of Navarra, Pamplona, Spain
}

(Received 11 April $1994-$ Accepted 7 June 1994)

\begin{abstract}
The effects of two different sources of protein: peas (Pisum sativum var. Belinda) and casein on immunocompetence, nutritional utilization and growth performance have been investigated in recently weaned mice. Feeding these animals on a pea diet resulted in an impairment in growth and significant decreases in the weights of liver, muscle, kidneys and femur, while intestine weights increased. No differences in food consumption were observed, but food conversion efficiency (food intake: weight gain) was increased in pea-fed animals compared with those offered the casein diet. Packed cell volume and serum $\mathrm{Fe}$ and $\mathrm{Zn}$ levels fell significantly after legume-protein intake, and, by contrast, $\mathrm{Cu}$ values increased slightly. Serum albumin levels showed a statistically significant reduction in mice fed on the diet containing peas. However, $\gamma$-globulins and immunoglobulin $\mathrm{G}$ titres were markedly increased. The characterization of spleen-cell subsets using monoclonal antibodies revealed a significantly higher percentage of T-lymphocytes in the pea group compared with casein-fed animals, while no changes were observed in the proportions of B-lymphocytes and macrophages. In vitro mitogenic responses to phytohaemagglutinin, concanavalin $A$ and Escherichia coli lipopolysaccharide $S$ were slightly, but not significantly, lower in the pea-fed animals. Our results describe, apparently for the first time in mice, some immunological disturbances after peak intake. These results may lead to a better understanding of the possible role of antigenic proteins in gastrointestinal disorders and the poor individual performance after legume intake.
\end{abstract}

Pea (Pisum sativum): Immune response: Nutritional status: Mice

Protein levels and the amino acid composition of the diet play a role in the maintenance of immune response (Bounous et al. 1983; Chandra, 1993; Yamauchi \& Suetsuna, 1993). Furthermore, proteins can act as dietary antigens (Perdue \& Bienestock, 1991) and the type of protein could affect the immune response through different antigenic or allergic reactions (Le Guen et al. 1991; Hankins et al. 1992; Lallès et al. 1993).

Food-induced allergic responses, especially in young individuals, have been the subject of study in recent years, and alternative protein sources in the treatment of protein allergies have been investigated (Walker, 1992). Moreover, the increasing use of plant proteins in human and animal nutrition has focused great attention on legumes, which are also important sources of other nutrients (Lallès et al. 1993). However, the immunogenicity of certain antinutritional factors such as lectins and some legume proteins seems to indicate that the immune response may be involved in digestive disturbances, impaired availability of different nutrients and reduced growth performance (Barratt et al. 1979; Grant et al. 1983; Lallès et al. 1993). These nutritional imbalances and others produced by the phytate, tannin or fibre content, which diminish mineral bioavailability (Larralde \& Martínez, 1989; Cashman \& Flynn, 1991 ; Rubio et al. 1992), may alter immune responses through complex interactions between nutrition and immunocompetence (Sherman, 1992; Chandra, 1993). 
The aim of the present study was to evaluate the immunocompetence in mice receiving diets containing peas (Pisum sativum var. Belinda) or casein as the source of protein using different indices of the immune response such as the total serum immunoglobulin $\mathrm{G}(\mathrm{IgG})$, the mitogenic response of splenic lymphocytes and the percentage of splenic-cell subsets. The nutritional utilization of different nutrients was also assessed. These studies may be of relevance in populations where legumes represent the staple food, but also for nutritional purposes in immunity or allergy-mediated disorders.

\section{MATERIALS AND METHODS}

Animals and diets

Recently weaned male Swiss albino mice (4 weeks old) obtained from Letica S.A. (Barcelona, Spain) and weighing about $21 \mathrm{~g}$ were randomly assigned to two dietary groups of eight animals each. The animals were housed in polypropylene cages with wire-meshed bottoms in a room with constant temperature $\left(20-22^{\circ}\right)$ and with a $12 \mathrm{~h}$ light-dark cycle. Feed and water were provided $a d$ lib. in feeders specially designed to minimize feed wastage. The diets contained casein (control) or raw pea seeds as the source of protein and were balanced for the remaining nutrients (Table 1). The animals were fed on the same experimental diets for 3 weeks. Mice and feed were weighed daily at the same time (09.00-10.00 hours). Final body and organ weights were assessed at the end of the experimental period as indices of growth performance.

\section{Packed cell volume and serum mineral measurements}

Mice were ether-anaesthetized and blood samples were obtained by cardiac puncture. Serum Fe was assayed colorimetrically using ferrozine as the chromogen (Thompsen \& Motola, 1984), and an Autoanalyser (model Cobas Fara; Roche Diagnostic, Basel, Switzerland). Packed cell volume values, as an index of Fe deficiency, were determined using capillary tubes by centrifugation at $1000 \mathrm{~g}$ for $10 \mathrm{~min}$.

Serum $\mathrm{Zn}$ and $\mathrm{Cu}$ determinations were made by atomic absorption spectroscopy (PerkinElmer, model $305 \mathrm{~B}$, Norwalk, CT, USA) with an air-acetylene flame at a wavelength of $213.9 \mathrm{~nm}$ for $\mathrm{Zn}$ and $324.7 \mathrm{~nm}$ for $\mathrm{Cu}$ (Smith et al. 1985).

\section{Serum protein and $\operatorname{IgG}$ determinations}

Serum total proteins, albumin and $\gamma$-globulins were measured after agarose-gel electrophoresis (Barta \& Porciau, 1984). Samples applied to agarose-gel plates were subjected to $100 \mathrm{~V}$ for $20 \mathrm{~min}$, then were scanned in a densitometer (Beckman Instruments, Brea, CA, USA) at $600 \mathrm{~nm}$.

Serum levels of IgG were measured by radial immunodiffusion (Hudson \& Hay, 1989) using a kit with anti-mouse IgG antiserum contained in agarose gel (Serotec, Oxford, Oxon). After an appropriate dilution, test samples and standards were applied in $5 \mu \mathrm{l}$ volumes on different wells of the plates. The incubations were carried out at $22^{\circ}$ in moist atmosphere for $72 \mathrm{~h}$. The diameters of the precipitation rings were measured and the concentrations of immunoglobulin in the samples were determined from a calibration curve.

\section{Isolation of mononuclear cells from spleen}

Spleens were removed aseptically from mice, weighed and briefly stored in $\mathrm{NaCl}$ solution $(8.5 \mathrm{~g} / 1)$ at $0^{\circ} \mathrm{C}$ before being washed and minced in the same solution. After removal of residual tissue, mononuclear cells of the cellular suspension were separated by density gradient centrifugation at $400 \mathrm{~g}$ for $20 \mathrm{~min}$ at room temperature on lymphocyte separation medium (1.083 g/ml; Lymphoprep, Nycomed AS; Böyum, 1983). Mononuclear cells were 
Table 1. Composition of experimental diets $(\mathrm{g} / \mathrm{kg})$

\begin{tabular}{lcc}
\hline \hline & Casein diet & Pea diet \\
\hline Casein* & 140 & - \\
Pea (Pisum sativum var. Belinda) & 350 & 600 \\
Sucrose & 350 & 150 \\
Wheat starch & 50 & 50 \\
Olive oil & 50 & - \\
Cellulose & 45 & 40 \\
Mineral mix $\dagger$ & 10 & 10 \\
Vitamin mix $\ddagger$ & $0 \cdot 6$ & 0.6 \\
Choline chloride & 15758 & 15591 \\
Energy content $(\mathrm{KJ} / \mathrm{kg})$ & 12.5 & 12.5 \\
Crude protein $(\mathrm{N} \times 6.25)$ & & \\
\hline \hline
\end{tabular}

* Methionine $(10 \mathrm{~g} / \mathrm{kg})$ was added to the casein diet.

$\dagger$ Harper mixture containing (g/kg): $\mathrm{NaCl} 130 \cdot 3, \mathrm{~K}_{2} \mathrm{HPO}_{4} \quad 389 \cdot 1, \mathrm{MgSO}_{4} .7 \mathrm{H}_{2} \mathrm{O} \quad 57 \cdot 3, \mathrm{CaCO}_{3} \quad 381 \cdot 4$, $\mathrm{FeSO}_{4} .7 \mathrm{H}_{2} \mathrm{O} 27 \cdot 0, \mathrm{MnSO}_{4} \cdot \mathrm{H}_{2} \mathrm{O} 4 \cdot 0, \mathrm{KI} 0 \cdot 79, \mathrm{CuSO}_{4} \cdot 5 \mathrm{H}_{2} \mathrm{O} 0.5, \mathrm{ZnSO}_{4} \cdot 7 \mathrm{H}_{2} \mathrm{O} 0 \cdot 12, \mathrm{CoCl}_{2} \cdot 6 \mathrm{H}_{2} \mathrm{O} 0.02$.

$¥$ Harper mixture containing $(\mathrm{mg} / \mathrm{g}$ ): retinol 0.5 , cholecalciferol $0 \cdot 37$, tocopherol $3 \cdot 0$, menadione $1 \cdot 5, p$ aminobenzoic acid $145, \gamma$-inositol $32 \cdot 5$, nicotinic acid $15 \cdot 0$, calcium pantothenate $5 \cdot 7$, riboflavin 1.5 , thiamine 14 , pyridoxine $9 \cdot 5$, pteroylmonoglutamic acid $0 \cdot 5$, cyanocobalamin $6 \cdot 0$, biotin $63 \cdot 0$. Lactose as carrier was added to make up to $1 \mathrm{~g}$.

collected at the interface and washed three times with saline solution. The final cell pellet was suspended in RPMI 1640 medium supplemented with foetal calf serum $(100 \mathrm{ml} / 1)$, 2 mM-L-glutamine, $10 \mathrm{~mm}$-4-(2-hydroxy-ethyl)-1-piperazine ethanesulphonic acid (HEPES), penicillin $100 \mathrm{units} / \mathrm{ml}$, and $100 \mu \mathrm{g}$ streptomycin/ml (Gibco, Grand Island, NY, USA). The cells were counted in a haemocytometer and cell viability, as determined by the trypan blue exclusion test, was $>97 \%$.

\section{Analysis of cell surface markers by flow cytometry}

Percentage of splenic cells was determined by flow cytometry (Hudson \& Hay, 1989). The following rat anti-mouse monoclonal antibodies were purchased from Serotec: anti-Thy 1 ( $T$ cells), anti H2-la subregion (B cells) and anti-Ly 40 (macrophage/monocyte). The cell pellets $\left(1 \times 10^{8}\right)$ were incubated with $50 \mu 1$ of the antibodies for $30 \mathrm{~min}$ on ice. After washing twice with phosphate-buffered saline the cell pellets were incubated with $50 \mu 1$ fluorescein isothiocyanate (FITC)-labelled anti-rat rabbit IgG. After washing twice with phosphatebuffered saline monoclonal antibodies binding to the cells were analysed with a fiuorescence-activated cell sorter (FACScan Flow Cytometer; Becton Dickinson, Erembodegem, Belgium). Fluorescence data were collected with logarithmic amplification. For each sample, data from 10000 volume-gated viable cells were collected. Nonmononuclear cells were gated on the basis of the forward and perpendicular light scatter signal.

\section{Lymphocyte proliferation to mitogen}

Cells were resuspended in RPMI supplemented at a concentration of $1 \times 10^{6} \mathrm{cells} / \mathrm{ml}$. Blastogenic response of splenocytes to the mitogens phytohaemagglutinin (PHA; Gibco, Grand Island, NY, USA), concanavalin A (Con A; Sigma Chemical Co., St Louis, MO, USA), and Escherichia coli lipopolysaccharide S (LPS; Difco, Detroit, MI, USA) was assessed by [methyl- ${ }^{3} \mathrm{H}$ ]thymidine incorporation, as previously described (Martínez et al. 1992). Triplicate cultures were set up in ninety-six-well microplates (Becton Dickinson). Splenocytes $\left(1 \times 10^{5}\right.$ cells in $100 \mu \mathrm{l}$ culture medium) were incubated with or without 


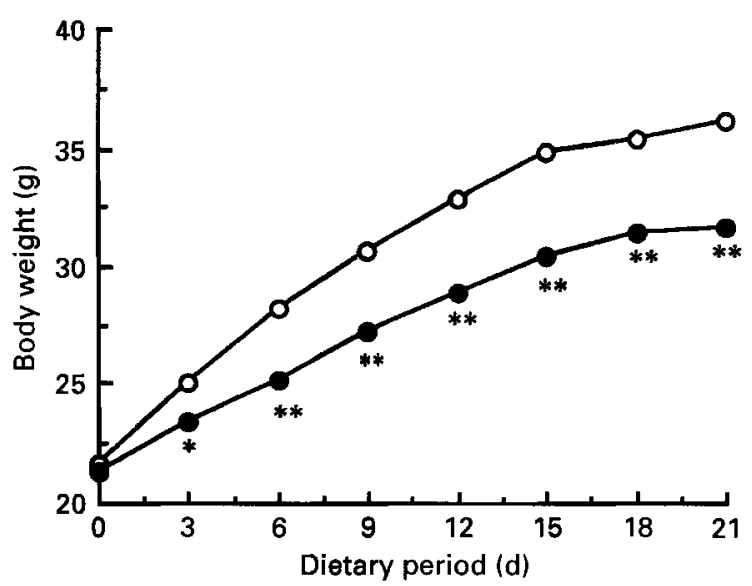

Fig. 1. Body weight gain of mice fed on diets containing casein $(O)$ or pea (Pisum sativum var. Belinda, $O)$ for $21 \mathrm{~d}$. Values are means for eight mice. The analysis showed a significant stunting of growth in mice fed on pea as the source of protein compared with those fed on casein: ${ }^{*} P<0.05,{ }^{* *} P<0.01$ (Student's $t$ test). For details of diets and procedures, see Table 1 and p. 88.

mitogens at $37^{\circ}$, in an $\mathrm{O}_{2}-\mathrm{CO}_{2}$ atmosphere $(95: 5, \mathrm{v} / \mathrm{v})$ for $72 \mathrm{~h}$. Doses of mitogens were $50 \mu \mathrm{g} / \mathrm{ml}$ for PHA, $5 \mu \mathrm{g} / \mathrm{ml}$ for Con A and $100 \mu \mathrm{g} / \mathrm{ml}$ for LPS. At $24 \mathrm{~h}$ before cell collection, $3.7 \times 10^{4} \mathrm{~Bq}\left[\right.$ methyl- $\left.{ }^{3} \mathrm{H}\right]$ thymidine (Amersham, Bucks) was added to each well. The cultures were then harvested onto fibreglass filter discs and counted in a liquid scintillation counter (LKB 1215). The data are expressed as a stimulation index, defined as a ratio of mean counts/min in stimulated cultures to that in unstimulated cultures of the same cells.

\section{Statistical analysis}

The results are presented as the arithmetic means with their standard errors for each casein and pea group. Differences among the means of groups were evaluated using the Student's two-tailed $t$ test and $P$ values $\leqslant 0.05$ were considered to be statistically significant.

\section{RESULTS}

\section{Growth performance and feed intake}

Mice fed on pea as the source of protein showed a retardation in growth compared with those fed on casein protein (Fig. 1). Although feed intake in the two groups was similar through the experimental trial, feed efficiency ratios, expressed as $g$ intake/g weight gain, were higher in the legume-fed animals $(P<0.01)$. Moreover, liver, gastrocnemius muscle, kidneys and femur weights were smaller in mice fed on the pea diet $(P<0.01)$, while an increase was observed in intestine weights $(P<0.05)$. No statistical differences were found in lymphoid organ weights between the experimental groups (Table 2).

\section{Packed cell volume and serum mineral measurements}

Packed cell volume showed a statistically significant decrease in those animals fed on the diet containing peas $(P<0 \cdot 01)$. Accordingly, serum Fe levels were found to be markedly reduced $(P<0.01)$. Serum $\mathrm{Zn}$ levels were also decreased in the legume-fed animals $(P<$ $0 \cdot 05)$. By contrast, $\mathrm{Cu}$ levels were slightly increased, while $\mathrm{Fe}: \mathrm{Cu}$ and $\mathrm{Zn}: \mathrm{Cu}$ ratios decreased $(P<0.05$ and $P<0.01$ respectively), suggesting an interaction in the uptake of these minerals (Table 3 ). 
Table 2. Initial and final body weights and organ weights, daily gain and feed-conversion ratio of mice given diets containing casein or peas (Pisum sativum var. Belinda) as the source of protein

(Mean values with their standard errors for eight mice per dietary group)

\begin{tabular}{|c|c|c|c|c|c|}
\hline & \multicolumn{2}{|c|}{ Casein } & \multicolumn{2}{|c|}{ Pea } & \multirow{2}{*}{$\begin{array}{l}\text { Statistical } \\
\text { significance }\end{array}$} \\
\hline & Mean & SE & Mean & $\mathbf{S E}$ & \\
\hline Initial body wt (g) & 21.9 & 0.3 & $21 \cdot 1$ & 0.3 & NS \\
\hline Final body wt (g) & 35.7 & 0.6 & 31.6 & 0.7 & $* *$ \\
\hline Daily gain $(\mathrm{g} / \mathrm{d})$ & 0.67 & 0.03 & 0.50 & 0.04 & * \\
\hline Feed conversion ratio $(\mathrm{g} / \mathrm{g}) \ddagger$ & $16 \cdot 1$ & 2.6 & $32 \cdot 5$ & $3 \cdot 6$ & ** \\
\hline \multicolumn{6}{|l|}{ Organ wt } \\
\hline Liver $(\mathrm{g})$ & 1.88 & 0.07 & 1.36 & 0.04 & ** \\
\hline Gastrocnemius (mg) & 336 & $5 \cdot 5$ & 283 & $7 \cdot 2$ & ** \\
\hline Kidneys (mg) & 532 & $13 \cdot 0$ & 449 & $13 \cdot 0$ & $* *$ \\
\hline Intestine (g) & $1 \cdot 50$ & 0.07 & 1.86 & $0 \cdot 11$ & * \\
\hline Femur (mg) & 130 & $3 \cdot 4$ & 103 & $7 \cdot 4$ & ** \\
\hline Thymus (mg) & 48 & 3.6 & 43 & $2 \cdot 7$ & NS \\
\hline Spleen (mg) & 177 & 24 & 173 & 30 & NS \\
\hline
\end{tabular}

NS, not significant.

$* P<0.05, * * P<0.01$ (Student's $t$ test).

$\dagger$ For details of diets and procedures, see Table 1 and p. 88 .

$\ddagger$ Food intake/g body weight gain.

Table 3. Packed cell volume and serum levels of iron, zinc and copper, of mice given diets containing casein or peas (Pisum sativum var. Belinda) as the source of protein $\dagger$

(Mean values with their standard errors for eight mice per dietary group)

\begin{tabular}{|c|c|c|c|c|c|}
\hline & \multicolumn{2}{|c|}{ Casein } & \multicolumn{2}{|c|}{ Pea } & \multirow{2}{*}{$\begin{array}{c}\text { Statistical } \\
\text { significance }\end{array}$} \\
\hline & Mean & SE & Mean & $\mathbf{S E}$ & \\
\hline Packed cell volume (\%) & $46 \cdot 0$ & $2 \cdot 1$ & $36 \cdot 6$ & $2 \cdot 3$ & ** \\
\hline Iron $(\mathrm{mg} / \mathrm{l})$ & $2 \cdot 71$ & 0.24 & $1 \cdot 20$ & 0.27 & $* *$ \\
\hline Zinc (mg/1) & 1.94 & $0 \cdot 19$ & 1.46 & 0.07 & $*$ \\
\hline Copper (mg/l) & 0.78 & 0.09 & 1.00 & 0.06 & NS \\
\hline Iron: copper & 3.80 & $0 \cdot 6$ & $1 \cdot 70$ & 0.4 & $*$ \\
\hline Zinc:copper & $2 \cdot 53$ & $0 \cdot 3$ & $1 \cdot 5$ & 0.1 & ** \\
\hline
\end{tabular}

NS, not significant.

* $P<0.05, * * P<0.01$ (Student's $t$ test).

$\dagger$ For details of diets and procedures, see Table 1 and p. 88.

\section{Serum protein and $\operatorname{Ig} G$ determinations}

Total serum proteins did not decrease significantly in mice fed on pea as the source of protein compared with casein-fed animals. However, serum albumin levels showed a marked decline $(P<0.05)$, while $\gamma$-globulins were increased $(P<0.01)$ in the legume-fed mice (Table 4).

Total serum IgG levels were increased in those animals fed on pea protein $(P<0.05)$, suggesting a systemic humoral immune response (Fig. 2). 
Table 4. Total serum protein, albumin and $\gamma$-globulins of mice given diets containing casein or peas (Pisum sativum var. Belinda) as the source of protein $\dagger$

(Mean values with their standard errors for eight mice per dietary group)

\begin{tabular}{|c|c|c|c|c|c|}
\hline & \multicolumn{2}{|c|}{ Casein } & \multicolumn{2}{|c|}{ Pea } & \multirow{2}{*}{$\begin{array}{l}\text { Statistical } \\
\text { significance }\end{array}$} \\
\hline & Mean & $\mathrm{SE}$ & Mean & $\mathbf{S E}$ & \\
\hline Total protein $(\mathrm{g} / \mathrm{l})$ & $59 \cdot 6$ & $1 \cdot 1$ & $57 \cdot 7$ & $1 \cdot 5$ & NS \\
\hline Albumin $(\mathrm{g} / \mathrm{l})$ & 34.8 & 0.5 & $32 \cdot 0$ & $1 \cdot 0$ & $*$ \\
\hline$\gamma$-Globulin (g/l) & 1.40 & $0 \cdot 1$ & $2 \cdot 10$ & 0.2 & $* *$ \\
\hline
\end{tabular}

NS, not significant.

* $P<0.05, * * P<0.01$ (Student's $t$ test).

$\dagger$ For details of diets and procedures, see Table 1 and p. 88 .

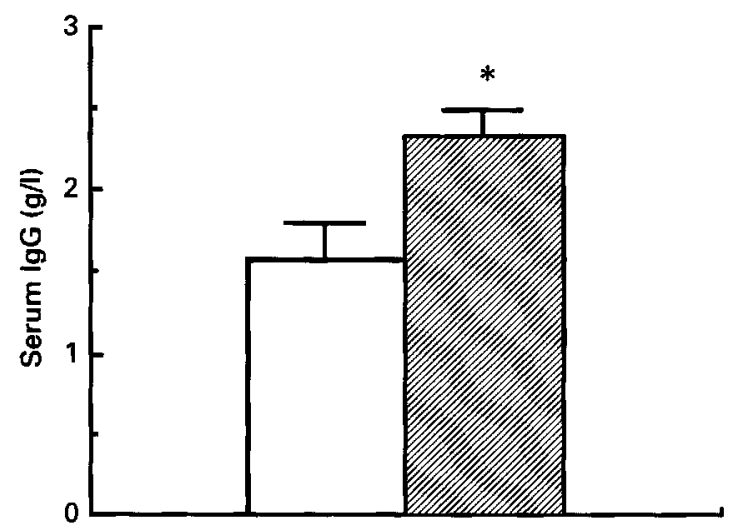

Fig. 2. Serum immunoglobulin G (IgG) levels in mice fed on diets containing casein ( $\square$ ) or pea (Pisum sativum var. Belinda, as the source of protein. Values are means for eight mice with their standard errors indicated by vertical bars. The analysis showed that IgG levels were significantly higher in mice fed on pea as the source of protein compared with those fed on casein: ${ }^{*} P<0.05$ (Student's $t$ test). For details of diets and procedures, see Table 1 and p. 88.

Table 5. Splenic-cell subsets (\%) of mice given diets containing casein or peas (Pisum sativum var. Belinda) as the source of protein $\dagger$

(Mean values with their standard errors for eight mice per dietary group)

\begin{tabular}{|c|c|c|c|c|c|}
\hline & \multicolumn{2}{|c|}{ Casein } & \multicolumn{2}{|c|}{ Pea } & \multirow{2}{*}{$\begin{array}{l}\text { Statistical } \\
\text { significance }\end{array}$} \\
\hline & Mean & $\mathbf{S E}$ & Mean & $\mathrm{SE}$ & \\
\hline T lymphocytes (Thy $1^{+}$) & $46 \cdot 9$ & $4 \cdot 5$ & $66 \cdot 4$ & $7 \cdot 1$ & $*$ \\
\hline B lymphocytes ( $\left.\mathrm{H} 2-\mathrm{Ia}^{+}\right)$ & $34 \cdot 8$ & $4 \cdot 0$ & $36 \cdot 8$ & $7 \cdot 2$ & NS \\
\hline Macrophages (Ly $40^{+}$) & $7 \cdot 7$ & $1 \cdot 3$ & $8 \cdot 5$ & $1 \cdot \overline{7}$ & NS \\
\hline
\end{tabular}

NS, not significant.

$* P<0.05$ (Student's $t$ test).

+ For details of diets and procedures, see Table 1 and pp. 88-89. 
Table 6. Mitogenic response (stimulation index, SI) of splenic lymphocytes of mice given diets containing casein or peas (Pisum sativum var. Belinda) as the source of protein $\dagger$

(Mean values with their standard errors for eight mice per dietary group)

\begin{tabular}{|c|c|c|c|c|c|}
\hline & \multicolumn{2}{|c|}{ Casein } & \multicolumn{2}{|c|}{ Pea } & \multirow{2}{*}{$\begin{array}{l}\text { Statistical } \\
\text { significance }\end{array}$} \\
\hline & Mean & $\mathrm{SE}$ & Mean & $\mathrm{SE}$ & \\
\hline PHA (SI) & $18 \cdot 7$ & 6.0 & $12 \cdot 2$ & 3.6 & NS \\
\hline Con A (SI) & 12.8 & 4.0 & $11 \cdot 2$ & 3.6 & NS \\
\hline LPS (SI) & 9.9 & 5.9 & 6.7 & $2 \cdot 1$ & NS \\
\hline
\end{tabular}

PHA, phytohaemagglutinin; Con A, concanavalin A; LPS, lipopolysaccharide; NS, not significant.

$\dagger$ For details of diets and procedures, see Table 1 and pp. 88-90.

\section{Spleen-cell subpopulations and mitogenic response of lymphocytes}

No statistically significant differences were observed in the percentage of B-lymphocytes and macrophages after the legume-diet intake. However, an increase was found in the splenic proportion of T-lymphocytes $(P<0.05)$, which could be explained by the immunoregulatory function of T-cells in antibody-dependent humoral response (Table 5).

The proliferative responses to T-cell mitogens (PHA and Con A) and B-cell mitogen (LPS) were slightly depressed in the animals fed on the pea-protein diet (Table 6).

\section{DISCUSSION}

There are many studies concerning the influence of dietary protein levels on the development of humoral and cellular immunity (Chandra, 1992, 1993), but only a few reports dealing with the influence of the type and quality of dietary protein on the immune system (Bounous et al. 1983; Yamauchi et al. 1993). Thus, although legumes are important sources of protein, little is known about the impact of feeding these seeds on the immune response. In this context we have studied a pea seed (Pisum sativum var. Belinda), which may be used for human nutrition and animal feeding as an important source of protein and other nutrients in different countries (Savage \& Deo, 1989).

Mice fed on peas as the source of protein showed a stunting of growth and organ weights at the end of the experimental period, but no changes in feed consumption. These effects could be attributed to a low utilization of different nutrients and the involvement of antinutritional factors (Larralde \& Martínez, 1989; Huisman et al. 1990). However, smallintestine weights showed a significant increase which some authors have attributed to the potential mitogenic activity of lectins and their capacity to stimulate crypt hyperplasia (Pusztai et al. 1986).

Serum $\mathrm{Fe}$ and packed cell volume decreased significantly in pea-protein-fed mice. These $\mathrm{Fe}$ alterations may involve a decrease in $\mathrm{Fe}$ storage, $\mathrm{Fe}$ transport and haemoglobin formation (Johnson, 1990). In addition, serum $\mathrm{Zn}$ levels, as a valid and useful indicator of the size of the exchangeable $\mathrm{Zn}$ pool, showed a significant decrease (King, 1990). The availability of these two minerals from legumes may be reduced by phytates, oxalates, tannins and other organic compounds occurring in legumes (Harland, 1989; Cashman \& Flynn, 1991; Rubio et al. 1992). This lower bioavailability could have implications for growth, metabolism and immunity (Mengheri et al. 1984; Martínez et al. 1985; Sherman, 1992). However, serum $\mathrm{Cu}$ showed a slight increase in the legume group and the $\mathrm{Fe}: \mathrm{Cu}$ and $\mathrm{Zn}$ : $\mathrm{Cu}$ ratios were significantly decreased. This could be explained by interactions among these minerals during absorption. Thus, chelating agents such as phytates and tannins 
might decrease $\mathrm{Fe}$ and $\mathrm{Zn}$ absorption and lead to a reduction in competitive interactions, which could increase $\mathrm{Cu}$ absorption (Gordon, 1987).

Serum albumin is the usual index of nutritional status in relation to protein intake (Gibson, 1990). In the present experimental trial, serum levels of this protein were significantly lower in legume-fed mice compared with the casein group. A poor content of S-amino acids reported in these seeds and a reduced nutritional utilization of protein affected by e.g. haemagglutinins and protease inhibitors (Savelkoul et al. 1992) could alter plasma protein turnover, which would be linked to a possible situation of subnutrition without external signs, induced by legume intake.

On the other hand, despite the fall in serum albumin levels, serum $\gamma$-globulins were markedly increased in mice fed on the diet containing the legume protein. Titres for serum IgG, which accounts for the major proportion of the $\gamma$-globulins, were also increased. It is well known that in normal physiological conditions the gut wall prevents the passage of dietary proteins from the intestinal lumen into the blood circulation. However, the chronic exposure of the small intestine to dietary antigens may cause a lesion to the gut mucosa which increases its permeability, allowing the entry of antigens through the impaired host barrier (Perdue \& Bienestock, 1991). Thus, the occurrence of antigenic proteins in peas could explain a loss of nutrients as a result of intestinal damage, the decrease in serum albumin levels and the poorer growth performance observed in mice fed on these seeds. Moreover, the rise of $\mathrm{IgG}$ titres is consistent with the passage of these antigens through the intestinal barrier.

Several authors have reported that digestive disturbances associated with feeding soyabean protein may be attributed to immune mechanisms (Barratt et al. 1978, 1979). Sissons and co-workers found a positive link between systemic anti-soya antibody titres and the severity of gastrointestinal disorders (Kilshaw \& Sissons, 1979; Sissons et al. 1989; Sissons \& Tolman, 1991). Pre-ruminant calves fed on diets containing high concentrations of soyabean protein developed long-lasting titres of circulating antibodies specific for soya-bean protein (Barratt et al. 1978, 1979). Similarly, early-weaned pigs fed on a diet containing soya-bean protein generated a systemic humoral immune response, which was specific for soya-bean protein ( $\mathrm{Li}$ et al. 1991). Furthermore, young piglets and calves given a raw-peabased diet developed circulatory antibodies against pea legumin and vicilin (Le Guen et al. 1991; Bush et al. 1992).

The expression of immune responses to feed antigens by animals depends on the nature of the antigen, the dose as well as the duration of exposure, age, immune status and genetic background of individuals (Crowe \& Perdue, 1992; Pollock et al. 1994). It is known that the newborn's gastrointestinal tract develops a mucosal barrier against penetration of a great variety and quantity of antigenic substances in food. This transition occurs at a time when systemic and local immunity systems are still immature (Strobel, 1990). Transient humoral and cellular immunodeficiencies have been reported in young piglets or at weaning (Hammerberg et al. 1989), while it has been proved that oral tolerance develops in older pigs (Wilson et al. 1989). In the present study the mice were recently weaned and, therefore, an immaturity in the immune system could explain the observed systemic humoral immune response.

In sensitized animals, immunological reactions to food can involve different types of mechanism. Although knowledge of the effects of immunologically mediated reactions on gut mucosal morphology and function has progressed rapidly in recent years, it is somewhat scanty and many aspects remain unknown (Strobel, 1990). In the present study the identification of cell subsets by monoclonal antibodies made it possible to identify an increase in the percentage of T-lymphocytes in mice fed on the pea diet. These results suggest a specific role for $T$-cells, which could be involved in a mucosal-cell-mediated 
immune response. The first sign of this reaction is an increase in intra-epithelial lymphocytes followed by an increase in crypt-cell turnover and elongation of the crypt compartment. Depending on the age of the animal, various degrees of villus atrophy have been observed (Strobel, 1990).

On the other hand, the systemic humoral immune response generated by some legume proteins could increase the $\mathrm{T}$-cell subset, which has an immunoregulatory function in antibody-dependent humoral response. Although the percentage of B-lymphocytes did not increase in the pea-fed mice, this may be because a significant increase in B-cells would only occur after polyclonal activation, while the stimulation by some pea antigens would only increase a small percentage of total B-cell clones. No alterations in macrophage: monocyte proportions were found after pea-protein intake, compared with casein protein.

Furthermore, the increase in T-cells could be attributed to a specific effect of some antinutritional factors on the immune system. Thus, lectins when passing from the intestinal lumen into the blood circulation, due to their mitogenic properties, may interact with T-lymphocytes modulating immune responses (Licastro et al. 1993). The role of these molecules as immunoenhancing agents in human diseases is being investigated (Wimer, 1990).

In vitro mitogenic assays are performed to study the functional behaviour of lymphocytes and, thus, a reduction in stimulation index may be an index of lymphocyte hyporeactivity (Hudson \& Hay, 1989). An impairment in lymphocyte stimulation responses to mitogens as a result of nutritional deficiencies has been reported (Sherman, 1992; Chandra, 1993). Lectins such as PHA and Con A, extracted from legumes, specifically stimulate most T-cell series and T-helper-cells respectively, while B-cell transformation is specifically achieved by the mitogenic agent LPS. In the present study the proliferative responses of splenocytes to PHA, Con A and LPS were lower in mice fed on the legume diet, although no statistical differences were found. Thus, the decrease in the mitogenic response after legume intake could be attributed to the poor utilization of proteins, $\mathrm{Fe}$ and $\mathrm{Zn}$ observed in this dietary group. Mice fed on other legumes such as faba bean (Vicia faba) have also shown a statistically significant decrease in the stimulation index (Martínez et al. 1992), which was slightly improved by $\mathrm{Zn}$ supplementation (Macarulla et al. 1992). Moreover, previous studies in mice fed on a diet containing peas as the source of protein have shown a significant decrease in interleukin-2 (IL-2) activity, which plays a central role in the generation and regulation of the immune response (Larralde et al. 1993). Zn-deficient diets have led to impairments in IL-2 activity (Dowd et al. 1986) and other immunological variables (Verma et al. 1988).

The present study describes a stunting in growth and a low utilization of different nutrients that could be attributed to the occurrence of some antinutritional factors and the poor content of S-amino acids in pea protein. Moreover, the systemic humoral immune response observed and the increase in T-lymphocytes could help to establish a better understanding of the possible role of antigenic proteins in gastrointestinal disorders and the poor individual performance after legume intake.

We thank the Government of Navarra for financial support (O.F. 725/91), and staff and members of the Department of Immunology from the University of Navarra for helpful assistance and discussions. Also, the careful reading of the manuscript by Professor D. A. T. Southgate (UK) is gratefully acknowledged.

\section{REFERENCES}

Barratt, M. E. J., Strachan, P. J. \& Porter, P. (1978). Antibody mechanisms implicated in digestive disturbances following ingestion of soya protein in calves and piglets. Clinical and Experimental Immunology 31, 305 -312. 
Barratt, M. E. J., Strachan, P. J. \& Porter, P. (1979). Immunologically mediated nutritional disturbances associated with soya-protein antigens. Proceedings of the Nutrition Society 38, 143-150.

Barta, O. \& Porciau, S. S. (1984). Electrophoresis. In Laboratory Techniques of Veterinary Clinical Immunology, pp. 116-122 [O. Barta, editor]. Springfield, IL: Charles C. Thomas.

Bounous, G., Létourneau, L. \& Kongshavn, P. A. L. (1983). Influence of dietary protein type on the immune system of mice. Journal of Nutrition 113, 1415-1421.

Böyum, A. (1983). Isolation of human blood monocytes with Nycodenz. A new non-ionic iodinate gradient medium. Scandinavian Journal of Immunology 17, 429-436.

Bush, R. S., Toullec, R., Cugant, I. \& Guilloteau, P. (1992). Effects of raw pea flour on nutrient digestibility and immune responses in the preruminant calf. Journal of Dairy Science 75, 3539-3552.

Cashman, K. \& Flynn, A. (1991). Effect of tannic acid on iron and zinc absorption from a model food system in sucking rats. Proceedings of the Nutrition Society 50, 185A.

Chandra, R. K. (1992). Protein-energy malnutrition and immunological responses. Journal of Nutrition 122 , 597-600.

Chandra, R. K. (1993). Nutrition and immunity in serious illness. Proceedings of the Nutrition Society 52, 77-84.

Crowe, S. E. \& Perdue, M. H. (1992). Gastrointestinal food hypersensitivity, basic mechanisms of pathophysiology, Gastroenterology 103, 1075-1095.

Dowd, P. S., Kelleher, J. \& Guillou, P. J. (1986). T-lymphocyte subsets and interleukin-2 production in zincdeficient rats. British Journal of Nutrition 55, 59-69.

Gibson, R. S. (1990). Principles of Nutritional Assessment. New York: Oxford University Press.

Gordon, D. T. (1987). Interactions among iron, zinc and copper. In AIN Symposium Proceedings, pp. 27-31 [O. A. Levander, editor]. Bethesda: American Institute of Nutrition Publications.

Grant, G., More, L. J., McKenzie, N. H., Stewart, J. C. \& Pusztai, A. (1983). A survey of the nutritional and haemagglutination properties of legume seeds generally available in the UK. British Journal of Nutrition $\mathbf{5 0}$, 207-214.

Hammerberg, C., Schurig, G. G. \& Ochs, D. L. (1989). Immunodeficiency in young pigs. American Journal of Veterinary Research 50, 868-874.

Hankins, C. C., Noland, P. R., Burks, A. W., Connaughton, C., Cockrell, G. \& Metz, C. L. (1992). Effect of soy protein ingestion on total and specific immunoglobulin $\mathbf{G}$ concentration in neonatal porcine serum measured by enzyme-linked immunosorbent assay. Journal of Animal Science 70, 3096-3101.

Harland, B. F. (1989). Dietary fibre and mineral bioavailability. Nutrition Research Reviews 2, $133-147$.

Hudson, L. \& Hay, F. C. (editors) (1989). Practical Immunology. Oxford: Blackwell Scientific Publications.

Huisman, J., Van der Poel, A. F. B., Van Leeuwen, P. \& Verstegen, M. W. A. (1990). Comparison of growth, nitrogen metabolism and organ weights in piglets and rats fed on diets containing Phaseolus vulgaris beans. British Journal of Nutrition 64, 743-753.

Johnson, M. A. (1990). Iron: nutrition monitoring and nutrition status assessment. Journal of Nutrition 120 , 1486-1491.

Kilshaw, P. J. \& Sissons, J. W. (1979). Gastrointestinal allergy to soyabean protein in preruminant calves. Antibody production and digestive disturbances in calves fed heated soyabean flour. Research in Veterinary Science 27, 361-365.

King, J. C. (1990). Assessment of zinc status. Journal of Nutrition 120, 1474-1479.

Lallès, J. P., Salmon, H., Bakker, N. P. M. \& Tolman, G. H. (1993). Effects of dietary antigens on health, performance and immune system of calves and piglets. In Recent Advances in Antinutritional Factors in Legume Seeds. EAAP Publication no. 70, pp. 253-270 [A. F. B. Van der Poel, J. Huisman and H. S. Sini, editors]. Wageningen: EAAP.

Larralde, J., Esparza, M. L. \& Martínez, J. A. (1993). Interleukin-2 and T-lymphocytes in mice fed on a legume diet. Proceedings of the Nutrition Society 52, 135A.

Larralde, J. \& Martínez, J. A. (1989). A reappraisal of the nutritional utilization of legumes. Revista Española de Fisiologia 45 Suppl., 225-232.

Le Guen, M. P., Tolman, G. M. \& Huisman, J. (1991). Antibodies formation against pea proteins in piglets. In Digestive Physiology in Pigs, [N. W. A. Verstegen, J. Huisman and L. A. den Hartog, editors]. Wageningen: Pudoc.

Li, D. F., Nelssen, J. L., Reddy, P. G., Blecha, F., Klemm, R. D., Giesting, D. W., Hancock, J. D., Allee, G. L. \& Goodband, R. D. (1991). Measuring suitability of soybean products for early-weaned pigs with immunological criteria. Journal of Animal Science 69, 3299-3307.

Licastro, F., Davis, L. J. \& Morini, M. C. (1993). Lectins and superantigens: membrane interactions of these compounds with $\mathrm{T}$ lymphocytes affect immune responses. International Journal of Biochemistry 25, 845-852.

Macarulla, M. T., Marcos, R., Martínez, J. A. \& Larralde, J. (1992). Humoral and cellular mediated immune responses in legume fed mice after zinc supplementation. Nutrition Research 12, 905-914.

Martínez, J. A., Barcina, Y. \& Larralde, J. (1985). Interrelationships between zinc supply and protein source in young and adult rats. Nutrition Reports International 32, 1037-1046.

Martínez, J. A., Macarulla, M. T., Marcos, R. \& Larralde, J. (1992). Nutritional outcome and immunocompetence in mice fed on a diet containing raw field beans (Vicia faba, var. minor) as the source of protein. British Journal of Nutrition 68, 493-503. 
Mengheri, E., Bises, G. \& Gaetani, S. (1984). Cell mediated immune response in rats fed diets with increasing amount of phytate. Nutrition Reports International 32, 1435-1445.

Perdue, M. H. \& Bienestock, J. (1991). Immunophysiology of the gut. Current Opinion in Gastroenterology 7, 421-431.

Pollock, J. M., Rowan, T. G., Dixon, J. B. \& Carter, S. D. (1994). Level of nutrition and age at weaning: effects on humoral immunity in young calves. British Journal of Nutrition 71, 239-248.

Pusztai, A., Grant, G. \& Oliveira, J. T. A. (1986). Local (gut) and systemic responses to dietary lectins. IRCS Medical Science 14, 205-208.

Rubio, L. A., Grant, G., Bardocz, S., Dewey, P. \& Pusztai, A. (1992). Mineral excretion of rats fed on diets containing faba beans (Vicia faba L.) or faba bean fractions. British Journal of Nutrition 67, $295-302$.

Savage, G. P. \& Deo, S. (1989). The nutritional value of peas (Pisum sativum). A literature review. Nutrition Abstracts and Reviews (Series A) 59, 65-87.

Savelkoul, F. H. M. G., Van der Poel, A. F. B. \& Tamminga, S. (1992). The presence and inactivation of trypsin inhibitors, tannins, lectins and amylase inhibitors in legume seeds during germination. A review. Plant Foods for Human Nutrition 42, 71-85.

Sherman, A. D. (1992). Zinc, copper, and iron nutriture and immunity. Journal of Nutrition 122, 604-609.

Sissons, J. W., Pedersen, H. E., Duvaux, C., Heppell, L. M. J. \& Turvey, A. (1989). Gut dysfunction and diarrhoea in calves fed antigenic soybean protein. In Recent Advances of Research in Antinutritional Factors in Legume Seeds, pp. 359-363 [J. Huisman, T. F. V. Van der Poel and I. E. Liener, editors]. Wageningen: Pudoc.

Sissons, J. W. \& Tolman, H. (1991). Antinutritional properties of soyabean antigens in calves. In Toxic Factors in Crop Plants, pp. 632-685 [J. P. F. D'Mello and C. M. Duffus, editors]. London: Butterworth.

Smith, J. C. Jr, Holbrook, J. T. \& Danford, D. E. (1985). Analysis and evaluation of zinc and copper in human plasma and serum. Journal of the American College of Nutrition 4, 627-638.

Strobel, S. (1990). Immunologically mediated damage to the intestinal mucosa. Acta Paediatrica Scandinavica 365 , Suppl., 46-57.

Thompsen, J. C. \& Mottola, A. (1984). Kinetics of the complexation of iron (II) with Ferrozine. Analytical Chemistry 56, 755-758.

Verma, P. C., Gupta, R. P., Sadana, J. R. \& Gupta, R. K. P. (1988). Effect of experimental zinc deficiency and repletion on some immunological variables in guinea-pigs. British Journal of Nutrition 59, 149-154.

Walker, W. A. (1992). Adverse food reactions in childhood: summary and future directions. Journal of Pediatrics 121, S4-S6.

Wilson, A. D., Stokes, C. R. \& Bourne, F. J. (1989). Effect of age on absorption and immune responses to weaning or introduction of novel dietary antigens in pigs. Research in Veterinary Science 46, 180-186.

Wimer, B. M. (1990). Characteristics of PHA-L4, the mitogenic isolectin of phytohemagglutinin, as an ideal biologic response modifier. Molecular Biotherapy 2, 4-17.

Yamauchi, F. \& Suetsuna, K. (1993). Immunological effects of dietary peptide derived from soybean protein. Journal of Nutritional Biochemistry 4, 450-457. 